\title{
肺動脈と気管支を自動縫合器で一括切離した 原発性肺癌手術症例の検討
}

\author{
林＼cjkstart雅太郎, 上田 和弘, 田中 俊樹*1, 濱野 公一
}

要 旨

解剖学的肺切除術に際してリンパ節の強固な癒着により, やむを得ず肺動脈と気管支を自動縫合器で一括切離することが ある. 過去 3 年間に当科で解剖学的肺切除が行われた原発性肺癌 160 例の内, 一括切離が 5 例に行われた. 全例女性で, 原 発肺葉は全例右下葉, 全例腺癌で, 病理病期は全例 $I$ 期であった. 全例完全鏡視下に手術を開始したが, 3 例で開胸へ移行し た．術前にリンパ節腫大を指摘されていた症例はなかったが，PET-CT では 3 例で複数のリンパ節に炎症を疑わせる FDG の集積を指摘されていた．平均 19 力月の観察期間において，一括切離に起因する有害事象を認めていない. 自動縫合器を使 用した肺動脈・気管支一括切離に関して否定的な報告はないが，推奨すべきとする報告もない. 症例集積に基づく成績の報 告が不可欠であるが, 少なくとも現時点では肺動脈・気管支一括切離はあらゆる回避策を講じた上での最終手段として考え るべきである.

索引用語 : 肺動脈, 気管支, 一括切離, 原発性肺癌, PET-CT pulmonary artery, bronchus, simultaneously stapled resection, primary lung cancer, PET-CT (positronemission tomography-computed tomography)

\section{はじめに}

リンパ節が肺動脈と気管支に強固に癒着している症例 では，切離予定部位で肺動脈や気管支を十分に分離出来 ないことがある. その場合の選択肢として, 切離予定部 位よりも末梢または中枢での切離に変更する, 気管支肺 動脈形成を行うなどが考えられる。ただし, 剥離中に温 存すべき肺葉の肺動脈を損傷した場合に，その肺葉を追 加切除しなければならないこともあり得る.

過去に当科では, 肺動脈と気管支の剥離が困難な症例 の一部に対し, 肺動脈と気管支を自動縫合器で一括切離 したことがある. リンパ節郭清が不十分になるのは問題 であるが, 現在まで一括切離に起因する合併症等を認め ていない，それらの症例の術中所見や背景因子などにつ

山口大学大学院器官病態外科学呼吸器外科

${ }^{* 1}$ 山口宇部医療センター呼吸器外科

原稿受付 2012年 2 月 22 日

原稿採択 2012年 6 月11日
いて検討し, 肺動脈・気管支一括切離の是非について考 察した.

\section{対象と方法}

2008 年 5 月 1 日から 2011 年 4 月 30 日までの 3 年間 に当科で原発性肺癌に対し区域切除術以上の手術を施行 した症例は 160 例であり，そのうち肺動脈・気管支一括 切離を行った症例は 5 例であった。 それら 5 例の術中所 見や背景因子などについて，後方視的に検討した.

患者背景を Table 1 に提示する. 5 例全例が女性で, 平 均年齢は $74 （ 62$ 84) 歳であった．粉塵曝露などの特殊 な職業歴を有する症例はなく, 軽度の契煙歴を 1 例で認 めるのみであった.

\section{結果}

自験例 5 例（Table 1）の原発巣は全例が右下葉で，全 例に右下葉切除術が施行された. 対象とした 160 例中で の右下葉切除術の割合は 29 例 $(18.1 \%)$ であり, 一括切 
Table 1 Patient Characteristics

\begin{tabular}{cccccccccc}
\hline Case & $\begin{array}{c}\text { Age } \\
\text { (year) }\end{array}$ & Sex & $\begin{array}{c}\text { Dust } \\
\text { exposure }\end{array}$ & $\begin{array}{c}\text { Primary } \\
\text { site }\end{array}$ & $\begin{array}{c}\text { Open } \\
\text { conversion }\end{array}$ & Histology & $\begin{array}{c}\text { Pathological } \\
\text { stage }\end{array}$ & $\begin{array}{c}\text { Lymph node } \\
\text { calcification }\end{array}$ & $\begin{array}{c}\text { Lymph node } \\
\text { uptake on PET }\end{array}$ \\
\hline 1 & 68 & F & no & RLL & yes & adeno & IA & no & yes (multiple) \\
2 & 74 & F & no & RLL & no & adeno & IA & no & no \\
3 & 62 & F & no & RLL & no & adeno & IB & no & yes (multiple) \\
4 & 82 & F & no & RLL & yes & adeno & IB & no & no \\
5 & 84 & F & no & RLL & yes & adeno & IB & yes (multiple) & yes (multiple) \\
\hline
\end{tabular}

F, female; RLL, right lower lobe; adeno, adenocarcinoma; PET, positron emission tomography

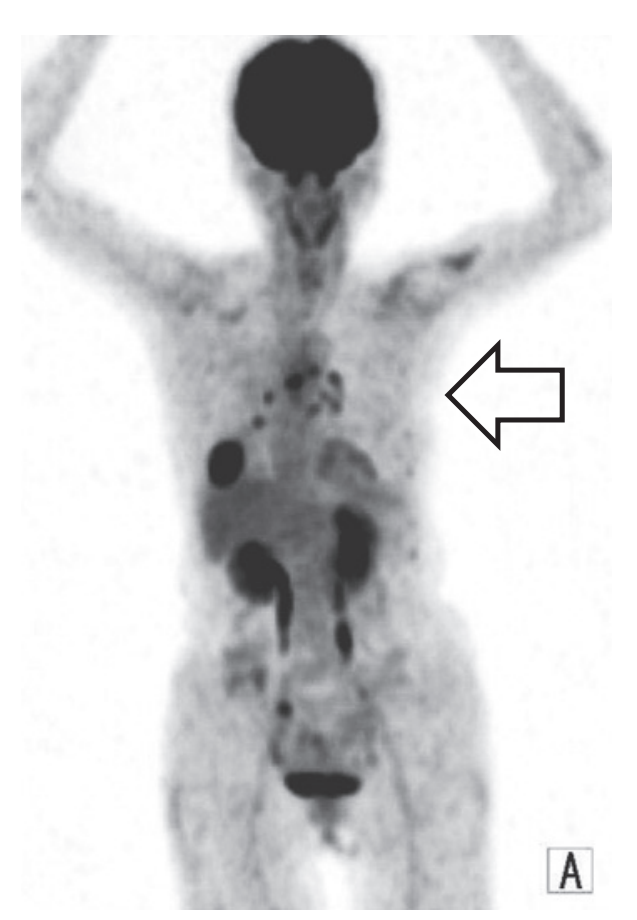

Fig. 1 FDG-PET demonstrated the accumulation of FDG in many hilar and mediastinal lymph nodes bilaterally.

離は全体の $3.1 \%$ に相当する. 5 例全例で完全鏡視下に手 術が行われたが, 3 例で開胸手術へ移行となった. 総肺底 動脈は処理できたが $\mathrm{A}^{6}$ のみ剥離が困難で, $\mathrm{A}^{6}$ と $\mathrm{B}^{6}$ のみ を一括切離した症例も 2 例あった。一括切離時の自動縺 合器は 1 例で Endo GIA60 (4.5) ${ }^{\circledR}$ を, 残りの 4 例で Echelon flex $45(4.1)^{\circledR}$ を使用した。一括切離した 5 例の手術時 間は $252 \pm 79$ 分 (平均 \pm 標準偏差, 184 分 385 分), 出 血量は $174 \pm 169 \mathrm{~g}$ (平均 標準偏差, $15 \mathrm{~g} \sim 450 \mathrm{~g}$ )であっ た. 一括切離を行わなかった右下葉切除症例 24 例の手術 時間は $208 \pm 73$ 分 (108 分〜390 分), 出血量は $135 \pm 144$ $\mathrm{g}(5 \mathrm{~g} \sim 500 \mathrm{~g})$ であり, 一括切離症例との間に有意差を
認めなかった（いずれも $\mathrm{p}>0.1 ）$.

いずれの症例も組織型は腺癌で, 病理病期は I期で あった. 術前の CT でリンパ節腫大を指摘されていた症 例はなかったが, 1 例で著明な石灰化を指摘されていた。 しかし PET-CTでは， 3 例で複数の肺門・縦隔リンパ節 に炎症を疑わせるFDGの集積を指摘されていた（Fig. 1). 周術期および遠隔期（最長で 40 カ月）に, 特筆すべ き合併症は認めていない.

\section{手術所見の一例（Case No.1）}

完全胸腔鏡下に右下葉切除術を開始した．葉間で肺動 脈を露出し観察したところ, 13 番リンパ節が総肺底動脈 の側面に強固に瘉着していた (Fig. 2). 肺動脈と下葉気管 支間の剥離を試みたが困難であったため, 未梢側で肺動 脈の分枝を剥離した。 まず $\mathrm{A}^{7}$ を剥離し, 結禁切離した。 次に $\mathrm{A}^{6}$ を剥離し, 結紮切離した.さらに $\mathrm{B}^{6}$ を剥離し, 結 禁切離した。この時点で再度肺動脈と気管支間の剥離を 試みたが, 肺動脈壁と気管支壁が直接強固に癒着してお り，剥離は困難であった，小開胸として様々な角度から 剥離を試みたが結局剥離できなかったため， $\mathrm{A}^{8-10}$ と総肺 底気管支を Echelon flex45 (4.1) ${ }^{\circledR}$ で一括切離し (Fig. 3)， 右下葉を摘出した.

\section{考察}

1995 年に Lewis は, 気管支・肺動脈・肺静脈を自動縫 合器で一括切離する肺葉切除術について報告している ${ }^{1}$. 心不全や腎不全などの合併症があるため標準開胸手術は 避けたいという理由で, 16 人の患者に対し胸腔鏡下に肺 葉切除術を行い, 平均 15 力月の観察期間であるが特筆す べき合併症は認めなかったという内容である。 その後さ らに症例を追加し, 1997 年に連続 100 症例での報告 ${ }^{2)} も$ 行っているが, やはり同様に特筆すべき合併症や問題点 


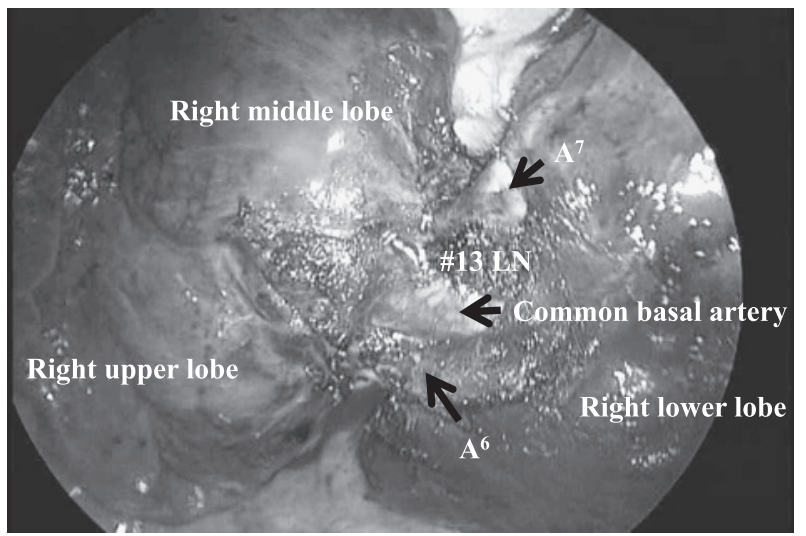

Fig. 2 Interlobar view of the right pulmonary artery. We found tight adhesion of the \#13 lymph nodes to the lateral side of the common basal artery.

は指摘されていない.さらに彼らは縦隔リンパ節生検や 気管支鏡検查を術前に施行し, 術中に複数のリンパ節を サンプリングすることにより，系統的な領域リンパ節郭 清を伴う標準開胸手術と比較して腫瘍学的な予後にも遜 色がなかったと付け加えている. 1999 年には症例数が 400 例となり最終報告が行われているが3), 手術時間は短 く, 患者の回復も早く, 医療費も少ないなど, 多くの利 点が記されている. 加えて, 問題になるような合併症の 記載はなかった。

ただこれらの報告ではいくつかの除外基準が設けられ ており，肺門に腫大したリンパ節が固着している状態で の一括切離は避けるべきであると付け加えられている.

Lewis らはまずリンパ節を郭清し, 気管支・肺動脈・肺 静脈を十分に剥離露出した後にこれらを一括切離してい る．ただ肺動脈と気管支が重ならないように並列に並べ てステイプリングしているわけではなく, 大部分は重 なったままステイプリングされている，つまり同一のス テイプルが, 肺動脈と気管支を貫通している状態である. 自験例においても腫大したリンパ節が付着したままの状 態でステイプリングしているわけではないので, 自験例 が Lewis らの提唱する除外基準に合致しているとはい えない.

前述のように一括切離例では, 気管支断端のトラブル は致命的になる可能性がある. 気管支断端㿉の予防目的 に, 有茎肋間筋弁や心膜周囲脂肪織などが気管支断端に 被覆される. しかし, 肺動脈・気管支一括切離後の肺動 脈気管支瘦の予防に断端被覆が有用であるか否かについ ては，不明のままである。

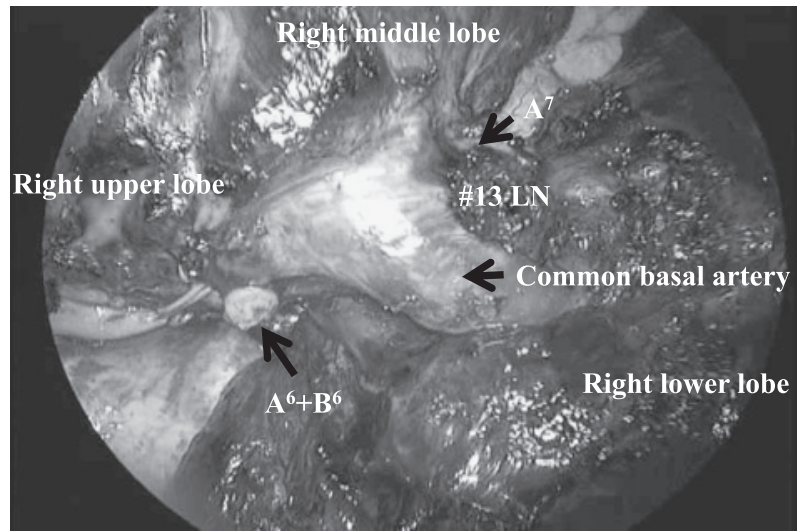

Fig. 3 After ligating and cutting $\mathrm{A}^{7}, \mathrm{~A}^{6}$, and $\mathrm{B}^{6}$, we stapled $\mathrm{A}^{8-10}$ and the common basal bronchus, simultaneously.

肺動脈・気管支一括切離の回避策の一つに, 肺動脈の みを糸針で掬い上げて結紮する方法も考えられる。しか し肺動脈と気管支との間に明らかなリンパ節が介在して いるような場合に限定されると推察する。予定切離線よ りも切離線を中枢側もしくは末梢側に変更するという選 択肢もある. しかし右下葉切除で切離線を中枢側に変更 した場合, $\mathrm{A}^{4+5}$ の温存が難しくなる可能性が高い. 一方, 上葉切除の場合は肺動脈形成が比較的容易であるため肺 動脈・気管支一括切離を回避することが可能である。こ のような理由から肺動脈・気管支一括切離が下葉切除症 例に集中するものと推察する。

リンパ節郭清に関しては，癒着したリンパ節が遺残す るため, 郭清が不十分になると言わざるを得ない。ただ 系統的リンパ節郭清の治療効果の有無については異論の あるところであり，肺実質を追加切除してまで癒着した リンパ節を切除すべきか否かについては画像所見などを 参考に個別的に判断する必要がある. PET-CTによる縦 隔リンパ節転移の診断能は, 感度が $85 \sim 89 \%$, 特異度が 84 94\% との報告がある ${ }^{4)}$. 術前の CT や PET-CT の所 見と術中迅速病理検查を併用することにより，癒着した リンパ節を切除せずとも，ある程度正確な $\mathrm{N}$ 因子診断は 可能と考える. 当科でも系統的な 2 群リンパ節郭清を行 えなかった場合には，肺門・縦隔リンパ節のそれぞれ 3 カ所以上からリンパ節をサンプリングし, 病理学的に評 価を行うように心がけている5

今回の我々の症例が全例女性であった理由について， 気道炎症・癒着・アレルギー・粉塵曝露などをキーワー ドとして論文を検索してみたが，性差に関する内容の論 
文は見あたらなかった．女性ホルモンの関与等が考えら れるが，詳細は不明である。

\section{結語}

PET-CT でリンパ流路に濔漫性の FDG 集積を認める 症例では, 肺動脈と気管支の炎症性癒着が存在する可能 性がある。自動縫合器を使用した肺動脈・気管支一括切 離に関して否定的な報告はないが，推奨すべきとする報 告もない. 多施設での症例集積に基づく成績の報告が不 可欠であるが，少なくとも現時点では肺動脈・気管支一 括切離はあらゆる回避策を講じた上での最終手段として 考えるべきである.
文献

1. Lewis RJ. Simultaneously stapled lobectomy: A safe technique for video-assisted thoracic surgery. J Thorac Cardiovasc Surg 1995; 109: 619-25.

2. Lewis RJ, Caccavale RJ, Sisler GE, Bocage JP, Mackenzie JW. One hundred video-assisted thoracic surgical simultaneously stapled lobectomies without rib spreading. Ann Thorac Surg 1997; 63: 1415-21; discussion 1421-2.

3. Lewis RJ, Caccavale RJ, Bocage JP, Widmann MD. Video-assisted thoracic surgical non-rib spreading simultaneously stapled lobectomy: a more patient-friendly oncologic resection. Chest 1999; 116: 1119-24.

4. 村上康二. PET/CT 検查. 気管支学 2008; 30: 347-53.

5. 日本肺癌学会編. 肺癌取扱い規約. 第 7 版. 東京 : 金原出 版 ; 2010: 51-4.

\title{
En bloc mass stapling of the pulmonary artery and bronchus during lobectomy for lung cancer
}

\author{
Masataro Hayashi, Kazuhiro Ueda, Toshiki Tanaka*1, Kimikazu Hamano \\ Department of Surgery and Clinical Science, Division of Chest Surgery, \\ Yamaguchi University Graduate School of Medicine \\ ${ }^{* 1}$ Department of Thoracic Surgery, NHO Yamaguchi-Ube Medical Center
}

En bloc stapling of the pulmonary artery and bronchus, combined, is an optional procedure during anatomical lung resection for patients with silicotic lymphadenitis. We performed simultaneous stapling of the pulmonary artery and bronchus in 5 of 160 patients who underwent major lung resection for cancer during a recent 3-year period. All five were women with a primary lesion in the right lower lobe and pathological stage I disease, with histologically confirmed adenocarcinoma. Although all operations were started thoracoscopically, three were converted to open surgery for anatomical assessment of the hilar region via direct vision. Despite this, the pulmonary arteries and bronchus could not be isolated. Although preoperative computed tomography (CT) suggested no lymphadenopathy, positron-emission tomographic (PET)-CT showed the diverse non-specific accumulation of FDG in the hilar and mediastinal lymph nodes, probably indicative of chronic lymphadenitis. All patients recovered uneventfully. There are no negative reports of en bloc stapling, but no one has recommended this procedure. Further attempts should be made to evaluate its long-term outcomes in more patients, and, at present, en bloc stapling should be considered as a last resort.

(C) The Japanese Association for Chest Surgery (JACS) 